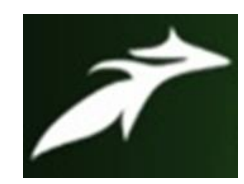

Ramakant Singh Sidar, International Journal of Advances in Agricultural Science and Technology,

Vol.2 Issue.11, November- 2015, pg. 57-63

ISSN: 2348-1358

\title{
Identification of Different Weeds on Mustard Crop with Special Reference to Herbicides: A Review
}

\author{
Ramakant Singh Sidar \\ RMD College of Agriculture and Research Station, Indira Gandhi Krishi Vishwavidyalaya \\ Ambikapur, Surguja-497001 (Chhattisgargh)
}

DOI: 10.47856/ijaast.2015.v02i11.001

\begin{abstract}
Mustard ( Brassica juncea I. Czern and Coss ) is one of the most important oilseed crops grown in the world. It is grown both in subtropical and tropical countries. The maximum productivity of mustard depends upon the best utilization of available resources and improved technology. Oilseeds constitute the second largest agricultural commodity in Indian economy after cereal accounting for nearly $6 \%$ of gross national product and $10 \%$ of the value of all agricultural product, although India is one of the leading oilseeds producing countries in the world it is not able to meet the requirement of edible oil for its vast population. Mustard occupies place being next to groundnut both in area and production, providing the fat requirement of about $50 \%$ population in all the northern states of the country. Among the different oilseeds, mustard occupies an area of $6.18 \%$ million hectares with 7.36 million tonnes of total production and productivity of $1190 \mathrm{~kg} / \mathrm{ha}$ in India and in Chhattisgarh total area under mustard cultivation is 145.27 hectares with a production of $595 \mathrm{~kg} / \mathrm{hectares}$. Mustard is grown in winter season in India and about two third area under this crop is irrigated. The importance of any crop is judged by its yield potential, nutrient content, keeping quality and market value. The low production and productivity of mustard have been due to various constraints like inadequate and untimely use of fertilizer, unavailability and unsatisfactory irrigation facility at all the critical stages of crop growth, inadequate plant protection measures adopted by the farmers and poor handling of post harvest techniques including deficiency in marketing support, storage and processing. Among the production constraints, weed infestation causes considerable loss of yield ranging from 15$30 \%$. Critical period of crop weed competition is $15-40$ days. Weeds compete with the crop plants for water, light, space and the required nutrients. The low productivity of mustard in the country might be the resultant of a number of factors viz. agronomic, edaphic, genetic and others. Among the agronomic factors, proper weed management may be a very serious issue (Singh 1992) Yield losses due to crop-weed competition in rapeseed-mustard have estimated to the tune of 10- 58\% (Bhan 1992, Banga and Yadav, 2001 and Singh et al. 2001) even ranging from 20-70 $\%$ depending upon the type of weed flora, magnitude and duration of weed infestation (Tiwari and Kurchania 1993) Competition by weeds at initial stages is a major limiting factor to its productivity.
\end{abstract}

Keywords: Weeds, mustard, herbicides and chhattisgarh 


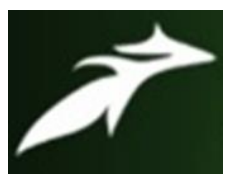

Ramakant Singh Sidar, International Journal of Advances in Agricultural Science and Technology,

Vol.2 Issue.11, November- 2015, pg. 57-63

ISSN: 2348-1358

\section{Introduction:}

Indian mustard (Brassica juncea) is an important winter (rabi) season oil seed crop. It is also known as Rai or Laha. In India it'is believed to be an introduction from China. It has been grown for oilseed, greens and as a spice. Mustard greens are an excellent source of vitamin $\mathrm{A}$, vitamin $\mathrm{B} 6$, vitamin $\mathrm{C}$, vitamin $\mathrm{E}$ and beta-carotene. It basically consists of folic, oleic, erucic and linoleic acids. The oil content varies from 37-49 per cent depending upon the type and variety of the crop. India is one of the leading oilseeds producing countries ranking third after United States of America and China with 21 per cent of world's area and 15 per cent of world's production. Oilseeds form the second largest agricultural commodity after cereals, sharing 13 per cent of the country's gross cropped area and accounts for nearly 5 per cent of gross national product (Reddy and Pati, 1998). In India, it occupies an area of 5,44, 500 hectares (Annual Report 2004) with production of 2,85,800 tormes (Annual Report 2003) accounting for 33 per cent of total output of oilseeds (Singh and Singh, 1998). In Himachal Pradesh, it covers an area of 8.9 thousand hectares with a production of 3.24 million tormes (Annual Report 2004). Among various components of production technology, weed control in Indian mustard needs due attention. As this crop is grown in poor soils with poor management practices, weed infestation is one of the major causes of low productivity (Singh and Singh, 1998).

The weeds depending upon the type, density and duration of competition accounts for 23-70 per cent reduction in yield of gobhi sarson (Tiwari 1998). Competition by weeds at initial stages is a major limiting factor to its productivity. However, during later stages the crop grows vigorously and has suppressing effect on weeds. Weeds are largely taken care manually. But manual weeding is tedious, cumbersome and labour intensive besides being costly. Therefore, chemical weed control is the only alternative for effective control. The most common herbicidal weed control measure recommend in Indian mustard is the preemergence application of pendimethalin. But it does not control all grassy weeds. Farmers 


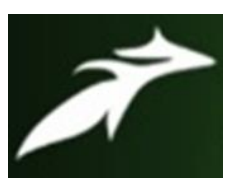

Ramakant Singh Sidar, International Journal of Advances in Agricultural Science and Technology, Vol.2 Issue.11, November- 2015, pg. 57-63

ISSN: 2348-1358

and extension functionaries require information on post emergence herbicidal weed control due to one or the other reason, if pre-emergence application of the herbicide was not made. Under situations when weeds are not taken care completely by pre-emergence application of herbicides, post-emergence herbicides may have an added economic advantage over super imposition of hand weeding. Therefore, it is imperative to find out an alternative weed management strategy for achieving season long weed control in Indian mustard. Keeping above points in mind, the present study entitled, Identification of different weeds on mustard crop with special reference to herbicides in Northern Hills zone of Chhattisgarh.

\section{Identification of different weeds on mustard:}

A review of literature of important aspects pertaining to present study is being presented. Attempt have been made to cite as some literature possible on mustard but due to paucity of adequate experimental evidences, especially on identification of different weeds on mustard crop, similar research work on other related crops has also been reviewed, wherever felt necessary:

Singh and Singh (1998) indicated that pre-plant incorporation of fluchloralin at $1.5 \mathrm{~kg}$ a.i./ha significantly reduced the density and biomass of weeds (Cyperus rotundus, Convolvulus arvensis and Anagallis arvensis) by 38.6 in first year and 46.1 per cent in second year, compared to unweeded control. Length of primary root, nodules/plant and dry weight of root were also enhanced significantly by fluchloralin application at $1.5 \mathrm{~kg}$ a.i./ha. Mishra and Kurchania (2001) registered that herbicide application reduced the biomass of Cichorium intybus, Medicago hispida, P. minor, Chenopodium album and V. sativa, but failed to control Cyperus rotundus, Anagallis arvensis and Convolvulus arvensis. Hand weeding was most effective in controlling weed dry matter accumulation, followed by oxadiazon. However, $1.0 \mathrm{~kg}$ isoproturon/ha gave the highest seed yield, net return, and benefit:cost ratio. Kurchania et al. (2002) it was reported by that isoproturon $1.0 \mathrm{~kg} / \mathrm{ha}$ reduced the population of major weeds, namely Phalaris minor, Medicago hispida, Melilotus alba, and Chenopodium album but not scarlet pimpernel (Anagallis arvensis). Sharma et al. (2007) found in their study at palampur, himachal pradesh India that main grassy weeds in 


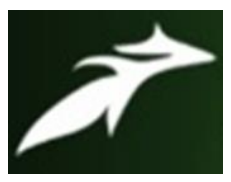

Ramakant Singh Sidar, International Journal of Advances in Agricultural Science and Technology, Vol.2 Issue.11, November- 2015, pg. 57-63

dominant mustard were Phalaris minor Retz, Avena fatua L. and Lolium temulentum L. whereas major broad leaf weed were Vicia sativa L., Coronopus didymus (L.) Sm. and Anagallis arvensis L. The broad leave weeds were present in low density. Punia et al. (2003) found that Indian mustard was affected by different weeds in Hisar Agriculture University (Haryana) as Asphodelus tenuifolis, C. album, Melilotus indica Trigonella polycerata, C. murale, Cynodon dactylon, Orobanche aegyptiaca, Carthamus oxycantha, A. ludoviciana and Convolvulus arvensis. Yadav et al. (2010) observed that the out of 16 weeds species, six weeds mamely Asphodelus tenuifolius, $C$. album, Melilotus indica, Trigonella polycerata, $C$. murale and Convolvulus arvensis was identified of dominating over other weeds specie present in Sirsa district. Meena, et al. (2011) found in a field experiment conduct in Punjab Agricultural University, on the resistance of three canola gobhi sarson verities viz., CSC-5, CSC-6 and Hyolia PAC-401 to the pre-emergence herbicide for three cropping season of 2007-2008, 2008-2009 and 2009-2010, that main weed flora field experimental included Phalaris minor between grasses and Medicago denticulate, Coronopus didymus with Rumex dentatus among broadleaves.

Results obtained by Singh-and Singh (1998) indicated that pre-plant incorporation of fluchloralin at $1.5 \mathrm{~kg}$ a.i. ha-1 significantly reduced the density and biomass of weeds (Cyperus rotundus, Convolvulus arvensis and Anagallis arvensis) by 38.6 in first year and 46.1 per cent in second year, compared to unweeded control. Length of primary root, nodules/plant and dry weight of root were also enhanced significantly by fluchloralin application at $1.5 \mathrm{~kg}$ a.i./ha. Mukherjee et al. (2003). Sprayed tobacco cv. C-403 plants with $1,1.5$ or $2 \mathrm{~kg}$ trifluralin/ha; $0.75,1$ or $1.25 \mathrm{~kg}$ fluchloralin/ha or $1,1.5$ or $2 \mathrm{~kg}$ pendimethalin/ha in a field experiment conducted in Haryana, India during the rabi seasons of 1998-2001. The experimental field was infested with Chenopodium album, C. murale, Anagallis arvensis, Spergula arvensis, Melilotus indica, Orobanche aegyptiaca and Argemone mexicana. Weed dry weight decreased with increasing rates of trifluralin, fluchloralin and pendimethalin. The average seed yield decreased with increasing rates of fluchloralin but increased with increasing rates of trifluralin and pendimethalin, which 


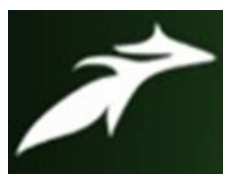

Ramakant Singh Sidar, International Journal of Advances in Agricultural Science and Technology, Vol.2 Issue.11, November- 2015, pg. 57-63

resulted to higher increments in seed yield compared to trifluralin. The slow initial growth of mustard provides congenial environment for the emergence, growth and development of weeds. In Himachal Pradesh, the major weed flora in mustard consisted of mainly grasses viz. Avena ludoviciana and Phalaris minor constituting 54.5 and 28.5 percent, respectively (Chopra and Saini, 2006). Sharma et al. (2007) reported grassy viz. Phalaris minor, Avena fatua, Lolium temulentum and broad-leaf viz. Vicia sativa, Coronopus didymus and Anagallis arvensis, the predominant weed species infesting gobhi-sarson at Palampur. Chauhan et al. (2005) reported Chenopodium album, Convolvulus arvenis, Asphodelus tenuifolius, Melilotus indica, Anagallis arvensis, Avena fatua, and Phalaris minor the major weeds in Indian mustard (Brassica juncea) at Gwalior in Madhya Pradesh. Mishra et al. (2001) reported Coronopus didymus (34\%), Avena ludovieiana (31\%), chenopodium album (18\%)) and Phalaris minor (17\%)) the major weeds associated with Indian mustard in Haryana. Bazaya et al. (2004) reported Medicago denticulata (23.3\%)), Anagallis arvensis (22.5\%), Lathyrus aphaca $(9.6 \%)$ and Vicia sativa (7.2\%) the major weeds in Indian mustard. Yadav (1999) reported that Asphodelus tenuifolius, Chenopodium album, Convolvulus arvensis, Anagallis arvensis and Cynodon dactylon were the major weeds in Indian mustard at Morena in Madhya Pradeshj, whereas, Butter and Aulakh (2003) reported that Asphodelus tenuifolius, Chenopodium album, Phalaris minor and Poa annua were the most dominant weeds in Indian mustard. Rana, (2006) reported that Cynodon dactylon, Asphodelus tenuifolius, Cyperus rotundus, Chenopodium album, Anagallis arvensis, Avena ludovieiana and Phalaris minor were the most dominant weeds in Indian mustard. Anand and Vaishva (2002) reported that the most dominant weeds in Indian mustard were Cynodon dactylon, Asphodelus tenuifolius, Cyperus rotundus, Chenopodium album, Anagallis arvensis, Vicia sativa, Medicago denticulata and Phalaris minor. Singh et al. (1990) reported Asphodelus tenuifolius, Chenopodium album and Chenopodium murale as the major weeds in Indian mustard. De and Reddy (1986) found that the weed flora of mustard consisted of both grasses $(45.6 \%))$ and broad- leaved weeds (54.4\%). 


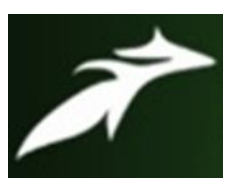

Ramakant Singh Sidar, International Journal of Advances in Agricultural Science and Technology,

Vol.2 Issue.11, November- 2015, pg. 57-63

ISSN: 2348-1358

\section{Conclusion:}

The literature reviewed in this paper highlighted the Identification of different weeds on mustard crop Knowledge of weeds between yield, seed yield and its components is very useful for efficient selection of desirable herbicides.

\section{References}

[1]. Annual Report (2003). Annual Progress Report of AICRP on Rapeseed Mustard (ICAR). National Research Centre on Rapeseed-Mustard Sewar, Bharatpur (Rajasthan) India. pp. A8.

[2]. Annual Report (2004). Annual Progress Report of AICRP on Rapeseed Mustard (ICAR). National Research Centre on Rapeseed-Mustard Sewar, Bharatpur (Rajasthan) India. pp. A26.

[3]. Banga R.S. and Yadav, A. (2001). Evaluation of herbicides against complex weed flora in Indian mustard. Haryana Journal of Agronomy : 17:48-51.

[4]. Bhan V.M. (1992). Weed management a factor for sustainability in crop production In: Proceeding of XII National Symposium on Resource Management for Sustained Crop Production, held At Rajasthan Agriculture University, Bikaner, 209-2016.

[5]. Kurchania, S.P., Rathi, G.S. Bhalla, C.S. and Mathew, R. (2002). Direct and residual effects of herbicides for weed control in soybean-mustard cropping system. Research Journal. 36(1/2): 13-16.

[6]. Meena, M.L. and Dinesh Sah (2011). Effect of weed control and fertilization on yield attributes and seed yield of mustard (Brassic juncea L.) under western plains of UP. Environment and Ecology;. 29: (2A), 929-931. 5.

[7]. Mishra, J.S. and Kurchania, S.P. (2001) Weed dynamics, nutrient uptake and yield in Indian mustard (Brassica juncea)-weed ecosystem as influenced by nitrogen levels, planting geometry and herbicides. Indian J. Weed Sci. 46(2): 296-303.

[8]. Mishra, P.J. and Sharma, S.N. (2001). Weed dynamics and dry matter production in mustard as influenced by fertility levels and weed management practices. Indian J. Weed Sci. 33(3/4): 151-155.

[9]. Mukherjee Dhiman and Singh R.P. (2003). Effect of integrated weed management in Indian mustard cuttivars (Brassica juncea) Haryana. J. Agron. 19(1): 8-10.

[10].Punia, S.S., Malik, R.K., Parvender, Sheoran and Sharma, S.D. (2003). Weed management studies in mustard (Brassica juncea (L.) Haryana J. Agron. 19 (1): 108109.

[11].Rana, D.S. (2006). Effect of planting patterns and weed management on weed suppression, productivity and economics of African mustard (Brassica carinata) and Indian mustard (Brassica juncea) intercropping. Indian Journal of Agricultural Sciences; 76: (2), 98-102. 6. 


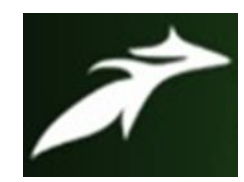

Ramakant Singh Sidar, International Journal of Advances in Agricultural Science and Technology,

Vol.2 Issue.11, November- 2015, pg. 57-63

ISSN: 2348-1358

[12].Reddy, A.R. and Patil A.P.K. (1998). Effect of different herbicides in controlling weed in yellow sarson. Abstract of papers presented at ${ }^{\wedge}$ nnual Conference of Indian Society of Weed Science, Jodhpur, 86 p.

[13].Sharma, R.P. and Singh, P. (2007). Effect of weed management and phosphorus levels on yield and quality of Indian mustard (Brassica juncea). Annals of Agri. Res. 24 (3): 605-609.

[14].Singh SS. (1992). Effect of fertilizer application and weed control on the yield of mustard (Brassica juncea). Indian Journal of Agronomy.; 37:196-198.

[15].Singh, B.D. and Singh, B.P. (1998). Effect of weed management practices and phosphorus levels on weed infestation, nodulation and yield of chickpea + mustard intercropping system. Indian J. Weed Sci. 30 (3/4): 124-128.

[16].Singh, Samunder, R.K., Malik, Balyan, R.S. (1990). Weed management studies in Raya (Brassicajuncea L.) Haryana J. Agron. 8 (1): 16-18.

[17].Singh, Harphool., Singh, B.P. and Prasad, Hanuman. (2001). Weed management in Brassica species. Indian J. Agron. 46 (3): 533-537.

[18]. Tiwari (1998). Weeds are regarded as one of the major negative factor of crop produce loss due to competitions for nutrients, moisture, light and space which have been reported as high as 30-70\%. Indian j. weed sci. 30: 149-152.

[19]. Tiwari J.P. and Kurchania, S.P. (1993). Chemical control of weeds in Indian mustard (Brassica juncea L.). Indian Agricultural Sciences; 63:272-275.

[20]. Yadav, R.P. 2010. Effect of herbicides alone and in combination with cultural method dn weed cohtrol in Indian mustard (Brassica juncea). Indian Journal of Agronomy 49: 268-270.

[21].Yadav, R.P., Shrivastava, V .K. and Dwivedi, S.C. (1999). Comparative efficiency of herbicide in controlling Asphodelus tenuifolius and other weed in Indian mustard (Brassica juncea). Indian J. Agron. 44 (1): 151-155. 